\title{
TINGKAT KESIAPAN KOTA SURAKARTA SEBAGAI KOTA NYAMAN BERSEPEDA
}

\author{
Tities Amrihtasari Suryono ${ }^{1}$, Paramita Rahayu ${ }^{1}$, Erma Fitria Rini 1 \\ ${ }_{1}^{1}$ Program Studi Perencanaan Wilayah dan Kota, Fakultas Teknik, Universitas Sebelas Maret
}

\begin{abstract}
Abstrak
Kota Surakarta merupakan kota menengah yang terus berkembang dengan total kendaraan bermotor sebanyak $85 \%$ dari total jumlah penduduk. Pemerintah Kota Surakarta saat ini mengalami kemacetan di banyak titik. Salah satu upaya untuk mengurangi kemacetan adalah dengan ditetapkannya Kota Surakarta sebagai kota nyaman bersepeda. Dalam kota nyaman bersepeda dibutuhkan integrasi antar aspek yaitu kebijakan dan kelembagaan, luas wilayah, jumlah penduduk kota, bentuk kota, infrastuktur yang dibagi menjadi jalur dan pakir sepeda, perbandingan pemilihan moda transportasi, dan sosial kebudayaan bersepeda. Tujuan penelitian ini adalah untuk mengetahui tingkat kesiapan Kota Surakarta sebagai kota nyaman bersepeda dan juga mengetahui tingkat kepentingan dari variabel kota nyaman bersepeda di Kota Surakarta. Penelitian ini menggunakan metode kuantitatif dengan menggunakan dua tahap analisis (1) analisis deskriptif untuk mengetahui kesiapan Kota Surakarta sebagai kota nyaman bersepeda yang dinilai pada setiap variabelnya (2) teknik Analytical Hierarchy Process (AHP) yang digunakan untuk memutuskan variabel mana yang mempunyai tingkat kepentingan tertinggi ke terendah terhadap kesiapan kota nyaman bersepeda. Hasil analisis menunjukkan bahwa variabel yang siap dalam konteks kota nyaman bersepeda adalah jumlah penduduk dan luas wilayah. Urutan prioritas variabel kota nyaman bersepeda di Kota Surakarta menurut para pelaku utama adalah jaringan/jalur sepeda, kebijakan dan kelembagaan, perbandingan pemilihan moda, sosial kebudayaan bersepeda, parkir sepeda, bentuk kota, jumlah penduduk, dan urutan terakhir adalah luas wilayah.
\end{abstract}

Kata kunci: kesiapan; kota nyaman bersepeda

\begin{abstract}
Surakarta City is a secondary city that continues to grow with the number of its motorized vehicles is as high as $85 \%$ of the total population. The Surakarta City is currently experiencing congestion at many points of travel. One effort to reduce the congestion is the establishment of the idea of Surakarta City as a friendly cycling city. The friendly cycling city requires integration of aspects such as policies and institutions, area size, population, city form, infrastructure divided into bicycle lane and parking, mode choice ratio, and social culture of cycling. Therefore, the purpose of this study was to determine the level of readiness of Surakarta City as a friendly cycling city and also to identify the level of importance of the friendly cycling city variables in Surakarta City based on the perceptions of the stakeholders. This study applies a quantitative method using two steps of analysis (1) descriptive analysis to determine the readiness of Surakarta City as a friendly city cycling which is assessed on each variable (2) Analytical Hierarchy Process (AHP) technique used to decide which variable has the highest importance to the lowest against the readiness of friendly city cycling. The results show that the variables that are ready in the context of a friendly city of cycling are the population and areawide. The next priorities are bicycle lane, policies and institutions, mode choice ratio, social culture of cycling, bicycle parking, city form, population, and the final sequence is the area.
\end{abstract}

Keywords: friendly city cycling; readiness

\section{PENDAHULUAN}

Kota merupakan tempat konsentrasi penduduk dan pusat aktivitas baik pemerintahan perekonomian, maupun sosial. Saat ini, pertumbuhan penduduk di sebuah kota setiap tahun tidak dapat dipungkiri semakin meningkat, hal ini menyebabkan pesatnya perkembangan di suatu kota. Semakin tinggi perkembangan kota maka akan semakin tinggi juga pergerakan masyarakatnya. Seringkali pergerakan ini menimbulkan masalah-masalah lingkungan seperti masalah transportasi. Masalah utama yang kerap terjadi di kota adalah tingginya penggunaan kendaraan bermotor (motorized) serta menurunnya penggunaan kendaraan non-motorized transport (NMT). Hal ini dapat mengakibatkan berbagai dampak transportasi seperti kecelakaan, kemacetan dan polusi. 
Untuk mengurangi dampak yang ditimbulkan dari permasalahan transportasi tersebut salah satunya yaitu dengan penerapan konsep Sustainable Transportation. Sustainable Transportation atau transportasi berkelanjutan dan berwawasan lingkungan dapat diartikan sebagai upaya untuk memenuhi kebutuhan mobilitas transportasi saat ini tanpa mengurangi kemampuan generasi mendatang dalam memenuhi kebutuhan mobilitasnya. Masalah transportasi seperti kecelakaan, kemacetan, dan polusi dapat diakomodasi dengan penggunaan NMT yang dianggap sebagai transportasi ramah lingkungan. Salah satu transportasi ramah lingkungan adalah sepeda.

Kota Surakarta tergolong dalam secondary city atau kota menengah yang terus berkembang. Dengan luas 44,04 $\mathrm{km}^{2}$ Kota Surakarta ditinggali oleh 514.171 atau dengan kepadatan sebesar 11.674,93 jiwa/km² (BPS, 2017). Tingginya pertumbuhan penduduk yang ada di Kota Surakarta tentu berdampak pada tingginya mobilitas masyarakat. Artinya ruang gerak di Kota Surakarta juga semakin sempit dan bisa timbul kemacetan. Terkait dengan perkembangan pertumbuhan kendaraan bermotor baru yang ada di Kota Surakarta cenderung mengalami peningkatan dengan jumlah peningkatan dari tahun 2010-2014 sebesar 29.373 unit dari 411.629 menjadi 439.417 (UP3AD, 2014)

Pemerintah Kota Surakarta saat ini sudah berupaya menerapkan beberapa alternatif untuk mengatasi kemacetan, salah satunya yaitu dengan ditetapkannya Kota Surakarta sebagai Kota Nyaman Bersepeda. Pengembangan kota nyaman bersepeda mensyaratkan terpenuhinya kondisi kenyamanan bagi para pesepeda di jalan, yaitu meliputi keamanan, kemudahan, dan keterjangkauan dan memiliki perjalanan yang menarik. Dalam penerapan kota nyaman bersepeda mengacu pada kota yang memiliki infrastruktur yang efisien, kebijakan transportasi dan keputusan bersama antar kemasyarakatan untuk menjadikan bersepeda sebagai moda transportasi utama (Zayed, 2016). Namun, dalam kondisi saat ini melalui perwakilan komunitas sepeda Solo, Didik menjelaskan jalur sepeda yang dibuat Pemerintah Kota Surakarta bisa dikatakan belum lengkap dan layak digunakan. Jalur sepeda di Jalan Dr. Radjiman di samping Matahari Singosaren, Kemlayan, Serengan, yang baru diperbaiki tahun lalu kerap dimanfatkan parkir kendaraan roda dua dan empat. Bahkan, pada malam hari ada pedagang kaki lima (PKL) yang membuka dasaran di jalur sepeda. Kebijakan yang terkait bersepeda saat ini juga masih relatif terbatas.

Dalam hal ini Kota Surakarta sudah mencoba untuk menerapkan konsep Sustainable Transportation dengan mencanangkan Kota Nyaman Bersepeda, walaupun dalam penerapannya di Kota Surakarta ini belum sempurna. Hal ini terlihat pada ketersediaan sarana dan prasarana penunjang pesepeda yang masih kurang. Untuk itu dalam penelitian ini penulis ingin mengetahui tingkat kesiapan Kota Surakarta sebagai kota nyaman bersepeda dan juga mengetahui tingkat kepentingan dari variabel kota nyaman bersepeda di Kota Surakarta.

\section{KAJIAN PUSTAKA}

Pada kajian teori ini akan menjabarkan tentang teori yang sesuai dengan penelitian yang dilakukan. Pustaka terkait antara lain mengenai transportasi berkelajutan, kota nyaman bersepeda, dan variabel penelitian.

\subsection{TRANSPORTASI BERKELANJUTAN}

Menurut Richardson, transportasi berkelanjutan didefinisikan sebagai suatu sistem transportasi yang penggunaan bahan bakar, emisi kendaraan, tingkat keamanan, kemacetan, serta akses sosial dan ekonominya tidak menimbulkan dampak negatif yang tidak dapat diantisipasi generasi yang akan datang (Richardson, 2000). Transportasi yang berkelanjutan (sustainable transportation) merupakan salah satu aspek keberlanjutan menyeluruh (global sustainability) yang memiliki tiga komponen yang saling berhubungan, yakni lingkungan, masyarakat, dan ekonomi. Dalam interaksi tersebut, transportasi memegang peran penting dengan perencanaan dan penyediaan sistem transportasi harus memperhatikan 3 pilar besar yaitu ekonomi, lingkungan, dan masyarakat/sosial.

a. Sosial

- Ketersediaan transportasi harus memenuhi kebutuhan dasar manusia untuk kesehatan, kenyamanan, dan kemudahan dengan cara-cara yang efektif dan tidak merusak tatanan sosial.

- Mendukung pembangunan yang berorientasi kepada masyarakat seperti menyediakan berbagai pilihan moda transportasi yang nyaman.

- Mengurangi polusi udara dan suara dari transportasi yang sangat mengganggu masyarakat

- Memberikan keamanan dan kenyaman bagi masyarakat

b. Ekonomi

- Sistem transportasi harus menyediakan layanan efektif dalam biaya dan kapasitas

- Sistem transportasi harus menjadi finansial yang terjangkau dalam setiap generasi 
- Sistem transportasi harus mendukung aktivitas hidup manusia, sehingga sistem transportasi juga berorientasi terhadap ekonomi berkelanjutan.

c. Lingkungan

- Sistem transportasi harus menggunakan tanah secara efektif dan efisien sehingga tanah yang digunakan lebih sedikit dan tidak berdampak besar terhadap integritas ekosistem.

- Sistem transportasi harus menggunakan sumber-sumber lain yang terbarukan atau sistem yang tak habishabisnya. Sumber terbarukan ini bisa didapat dengan mendaur ulang bahan yang telah digunakan dalam kendaraan umum atau infrastruktur.

- Menghasilkan sedikit emisi

Salah satu prinsip dasar menuju terciptanya transportasi berkelanjutan adalah berkelanjutan dalam lingkungan (Tamin, 2007). Lingkungan lokal di suatu pemukiman banyak yang rusak akibat jumlah kendaraan bermotor yang terlalu banyak. Dampak lokal sektor transportasi tersebut adalah polusi udara dan suara (kebisingan), yang banyak ditemukan di kota-kota besar di Asia. Terbukti bahwa tempat-tempat yang mempunyai sistem transportasi yang mempunyai dampak kecil terhadap lingkungan adalah tempat-tempat yang penggunaan kendaraan pribadinya rendah dan penggunaan kendaraan umum, pejalan kaki, dan bersepeda yang tinggi.

\subsection{KOTA NYAMAN BERSEPEDA}

Istilah kota ramah sepeda, atau kota yang ramah sepeda seperti yang digunakan di Amerika Utara, mengacu pada kota yang memiliki infrastruktur yang efisien, kebijakan transportasi dan keputusan bersama antar kemasyarakatan untuk menjadikan bersepeda sebagai moda transportasi utama. Disinilah otoritas lokal berfokus untuk membuat kota lebih ramah orang dan ramah lingkungan daripada ramah kendaraan bermotor (Kristinsdottir, 2012). Jenis kota seperti ini dapat menciptakan ruang yang lebih cocok untuk bersepeda (Williams, 2015). Maka dari itu, sepeda merupakan sarana transportasi untuk penduduk kota, terutama untuk perjalanan jarak pendek (Joo, Oh, Jeong, \& Lee, 2015).

Menurut Adisasmita (2012), salah satu penilaian kinerja transportasi adalah dari segi kenyamanan. Kenyamanan transportasi dalam hal ini berarti terwujudnya ketenangan dan kenikmatan bagi penumpang selama menggunakan atau berada dalam sarana transportasi. Kinerja aspek kenyamanan dapat diukur melalui meninjau ketersediaan dan kualitas fasilitas terhadap standar yang berlaku. Hal ini juga berlaku untuk pesepeda. Kenyamanan bersepeda merupakan hal yang penting untuk diperhatikan. Berikut merupakan kriteria untuk menilai kesiapan kota ramah bersepeda (Zayed, 2016) dan menurut kriteria kota ramah bersepeda copenhagenize index (Copenhagenize, 2011) yang disintesis penulis untuk mengetahui variabel kesiapan kota nyaman bersepeda (lihat Tabel 1).

Tabel 1. Sistesis Variabel

\begin{tabular}{|c|c|c|}
\hline $\begin{array}{c}\text { An index of city readiness for } \\
\text { cycling Mohamed Anwer Zayed, } 2016\end{array}$ & $\begin{array}{l}\text { The Criteria For The Copenhagenize } \\
\text { Index, } 2011\end{array}$ & Sistesis \\
\hline & $\begin{array}{l}\text { Advokasi } \\
\text { Politik } \\
\text { Program berbagi sepeda } \\
\text { Pengembangan cargo bike }\end{array}$ & Kebijakan dan kelembagaan \\
\hline $\begin{array}{l}\text { Luas area kota } \\
\text { Jumlah penduduk } \\
\text { Bentuk kota } \\
\text { Panjang jaringan jalan }\end{array}$ & & $\begin{array}{l}\text { Luas wilayah } \\
\text { Jumlah penduduk } \\
\text { Bentuk kota }\end{array}$ \\
\hline & $\begin{array}{l}\text { Perencanaan kota } \\
\text { Fasilitas sepeda } \\
\text { Infrastuktur sepeda } \\
\text { Kondisi kecepatan }\end{array}$ & Infrastruktur \\
\hline Pemilihan moda & $\begin{array}{l}\text { Perbandingan moda transportasi } \\
\text { Peningkatan perbandingan moda } \\
\text { transportasi }\end{array}$ & $\begin{array}{l}\text { Perbandingan pemilihan moda } \\
\text { transportasi }\end{array}$ \\
\hline & $\begin{array}{l}\text { Budaya bersepeda } \\
\text { Penerimaan sosial } \\
\text { Keselamatan berkendara } \\
\text { Gender }\end{array}$ & $\begin{array}{l}\text { Sosial kebudayaan mengenai } \\
\text { bersepeda }\end{array}$ \\
\hline
\end{tabular}




\subsection{PENJABARAN VARIABEL}

\subsubsection{KEBIJAKAN DAN KELEMBAGAAN}

Kebijakan adalah serangkaian tindakan yang mempunyai tujuan tertentu yang mesti diikuti dan dilakukan oleh para pelakunya untuk memecahkan suatu masalah (Anderson, 1979). Kebijakan ini akan menjadi batasan-batasan bagi perencanaan yang akan dilakukan. Dalam hal ini kebijakan yang ditetapkan pemerintah memainkan peran penting bagi masyarakat untuk membentuk karakter budaya bersepeda. Dalam copenhagenize index, disebutkan terdapat perencanaan dimana disini peran kebijakan dapat berperan aktif untuk merencanakan dan merancang penempatan infrastuktur sepeda.

Kelembagaan merupakan hal yang tak kalah penting untuk keberlangsungan kota bersepeda dimana dalam hal ini lembaga dapat bersifat formal dan non-formal. Dalam copenhagenize index dijelaskan pula peran kelembagaan yaitu advokasi yang terorganisir untuk memberikan pengaruh pada kebijakan mengenai bersepeda. Lembaga dalam kota bersepeda dapat berupa komunitas yang bisa dijadikan untuk perpanjangan tangan dinas atau lembaga yang berada di atasnya untuk membantu melakukan sosialisasi dari kebijakan atau peraturan yang sudah ditetapkan, sehingga masyarakat akan lebih teredukasi akan kebijakan yang telah ditetapkan.

\subsubsection{JUMLAH PENDUDUK}

Jumlah penduduk dapat mempengaruhi kebutuhan transportasi (Wahab, 2005). Jumlah penduduk kota bersepeda disebutkan oleh Zayed (2016) yaitu antara 223.200 jiwa hingga 3.292 .400 jiwa. Jumlah penduduk ini mempunyai hubungan langsung secara kuantitas dengan kebutuhan pergerakan. Semakin banyak kebutuhan pergerakan manusia maupun barang maka akan semakin banyak pula pengguna kendaraan pribadi sebagai moda transportasi darat. Hal ini tentunya dapat mempengaruhi volume kendaraan lalu lintas. Sehingga apabila kondisi jalan tidak mempunyai pembatas antara jalur pesepeda dengan kendaraan bermotor dapat mengganggu kenyamanan satu sama lain terutama bagi pengguna pesepeda.

\subsubsection{PERBANDINGAN PEMILIHAN MODA}

Dalam interaksi antara dua tata guna lahan di suatu kota, seseorang akan memutuskan bagaimana interaksi tersebut harus dilakukan. Sering interaksi tersebut mengharuskan terjadinya perjalanan. Keputusan dalam pemilihan moda berkaitan dengan jenis transportasi yang digunakan. Pemilihan moda ini juga dapat diartikan sebagai pembagian perjalanan yang dilakukan oleh pelaku perjalanan ke dalam moda yang tersedia dengan berbagai faktor yang memperngaruhi. Menurut Zayed (2016), dengan mengetahui rasio dari pemilihan moda antara penggunaan transportasi publik, pribadi maupun bersepeda dapat menggambarkan bagaimana ketergantungan suatu kota terhadap transportasi di suatu kota.

\subsubsection{BENTUK KOTA}

Ekspresi keruangan morfologi kota secara umum dapat dibagi menjadi dua, yaitu bentuk kompak dan bentuk tidak kompak (Yunus, 2000). Bentuk kota yang kompak mampu mereduksi jarak tempuh perjalanan sehingga dapat menurunkan tingkat mobilisasi penduduk di sebuah kota (Jenks, 2000). Bentuk kota yang kompak ini mempunyai salah satu gagasan yang kuat yaitu terletak pada perencanaan urban containment, yakni menyediakan suatu konsentrasi dari penggunaan campuran secara sosial berkelanjutan (socially sustainable mixed use), mengkonsentrasikan pembangunan-pembangunan dan mereduksi kebutuhan jalan hingga mereduksi emisi kendaraan-kendaraan (Elkin, 1991). Kepadatan tinggi dapat membantu membuat persediaan fasilitas pendukung dan yang secara ekonomis layak, serta mempertinggi keberlanjutan sosial (Haughton, 1997).

Kota kompak mencakup seluruh area kota, dan bukan hanya pada pusat-pusat pelayanan. Masyarakat yang hidup pada kota yang kompak mencakup seluruh area kota, dan bukan pusat kegiatan seperti pusat perbelanjaan, tempat kerja dan lain-lain (Neuman, 2005). Masyarakat dapat mencapai dengan berjalan, bersepeda, ataupun dengan moda transportasi berbasis transit. Sehingga didapatkan bahwa bentuk fisik kota yang kompak mampu menunjukkan seberapa panjang perjalanan yang dapat ditempuh menuju suatu tempat. Semakin kompak suatu kota karena semua aktivitas terkonsentrasi pada suatu tempat maka lama perjalanan juga semakin sedikit dikarenakan semakin mudahnya alat transportasi seperti sepeda untuk menjangkau berbagai tujuan. 
Untuk menghitung kekompakkan suatu kota diperlukan perhitungan matematis. Menurut Zayed (2016), untuk mengukur rasio kekompakkan kota dilakukan dengan cara membagi panjang perimeter dengan luas area bruto. Pendapat lain dari Richardson (2000) menghitung kekompokkan yaitu dengan cara:

$$
c=2 \sqrt{\pi \cdot A} / P
$$

Dimana,

$c=$ Rasio kekompakkan kota

$A=$ Luas area terbangun

$P=$ Panjang dari perimeter lahan yang terbangun

Rasio bernilai antara $0-1$.

Selain melihat dari hitungan matematis menurut (Asidiqi, 2017), terdapat tiga komponen untuk dapat melihat urban compactness yaitu kepadatan yang tinggi, keragaman penggunaan lahan (mix use), dan transportasi publik. Agar dapat dilihat tingkat kekompakkan melalui tiga komponen tersebut maka harus melihat pada skala kelurahan dikarenakan penggunaan jarak tempuh pada pesepeda juga terbatas.

\subsubsection{INFRASTRUKTUR}

Bersepeda adalah opsi transportasi bebas emisi, sehat dan terjangkau, yang sangat efisien dan mengkonsumsi sedikit sekali ruang dan sumber daya perkotaan. Bersepeda menggabungkan kenyamanan perjalanan door-to-door, fleksibilitas rute dan jadwal layaknya berjalan kaki, serta jangkauan dan kecepatan layaknya layanan angkutan umum. Namun demikian, pesepeda juga merupakan salah satu pengguna jalan yang paling rentan. Sepeda rentan terhadap pencurian dan perusakan. Faktor utama yang dapat mendorong orang untuk bersepeda adalah penyediaan infrastruktur yang memberikan keamanan dan keselamatan, seperti fasilitas parkir dan penyimpanan sepeda yang aman. Sehingga kota yang nyaman bersepeda haruslah memiliki fasilitas yang dapat mendukung pengendara sepeda ke tempat tujuan mereka. Menurut TOD Standar (Policy, 2014) prinsip kota bersepeda dibagi menjadi:

1. Jaringan infrastruktur bersepeda, syarat jaringan yang aman dan lengkap adalah:

a. Jalan dengan kecepatan rata-rata di atas $30 \mathrm{~km} / \mathrm{jam}$ atau $20 \mathrm{mph}$ harus memiliki jalur atau lajur khusus sepeda yang terlindungi untuk kedua arahnya. Menurut Peraturan Menteri No 111 Tahun 2015 kelas jalan yang diperbolehkan melebihi $30 \mathrm{~km} / \mathrm{jam}$ adalah jalan arteri primer, arteri sekunder, kolektor primer, dan kolektor sekunder.

b. Jalan dengan kecepatan rata-rata rendah ( $30 \mathrm{~km} / \mathrm{jam}$ atau $20 \mathrm{mph}$ atau kurang) dianggap aman untuk bersepeda dan tidak memerlukan jalur atau lajur khusus sepeda, tetapi dianjurkan menggunakan marka stensil 'sharrow' yang merupakan marka petunjuk untuk jalur khusus sepeda. Menurut Peraturan Menteri No 111 Tahun 2015 kelas jalan yang diperbolehkan antara $15-30 \mathrm{~km} / \mathrm{jam}$ adalah lokal primer dan lokal sekunder.

c. Jalan-jalan dengan prioritas pejalan kaki, atau jalan lingkungan, (dengan kecepatan $15 \mathrm{~km} / \mathrm{jam}$ atau $10 \mathrm{mph}$ atau kurang) dianggap aman untuk bersepeda.

2. Parkir sepeda di stasiun angkutan umum

a. Tempat parkir sepeda yang aman adalah fasilitas permanen yang disediakan untuk mengunci sepeda dan atau kendaraan tidak bermotor lainnya. Tempat parkir ini tersedia dalam jumlah banyak dan/atau memiliki perlindungan terhadap cuaca.

b. Fasilitas parkir sepeda harus ditempatkan di luar ruang sirkulasi pejalan kaki atau kendaraan lain dan terdapat di dalam radius 100 meter dari pintu masuk stasiun angkutan umum.

\subsubsection{SOSIAL KEBUDAYAAN BERSEPEDA}

Keadaan sosial budaya merupakan hal pokok dimana masyarakat menjadi subyek untuk membuat sebuah kota menjadi kota bersepeda. Kebudayaan bersepeda dapat dibentuk ketika sudah menjadi kebiasaan masyakarat (Copenhagenize, 2011). Dimana masyarakat sudah mampu untuk menerima bahwa bersepeda merupakan transportasi utama yang digunakan. Sosial kebudayaan bisa mulai dibentuk melalui sosialisasi yang mengedukasi bahwa sepeda bisa digunakan sebagai alat transportasi yang ramah lingkungan, sosialisasi ini dilakukan oleh lembaga atau komunitas. 


\section{METODE PENELITIAN}

Penelitian ini menggunakan pendekatan deduktif dengan jenis penelitian kuantitatif. Teknik pengumpulan data dalam penelitian ini dibagi menjadi 2 yaitu teknik pengumpulan data primer dengan observasi lapangan dan kuesioner untuk mendapatkan nilai kepentingan tiap variabel dari stakeholder terpilih atau key person serta teknik pengumpulan data sekunder yaitu dengan studi dokumen yang telah tersedia di lembaga maupun instansi. Pada Tabel 2 merupakan variabel dan parameter yang digunakan pada penelitian ini:

Tabel 2. Variabel dan Parameter Penelitian

\begin{tabular}{|c|c|c|c|}
\hline Variabel & Sub Variabel & Parameter & Sumber \\
\hline Luas wilayah & - & $49,4 \mathrm{~km}^{2}-891,6 \mathrm{~km}^{2}$ & Zayed (2016) \\
\hline Jumlah penduduk & - & 223.200 jiwa - 3.292 .400 jiwa & Zayed (2016) \\
\hline $\begin{array}{l}\text { Perbandingan } \\
\text { pemilihan moda }\end{array}$ & - & $0,1-1,9$ & Zayed (2016) \\
\hline & Rasio kekompakkan kota & $0,2-0,8$ & Zayed (2016) \\
\hline Rentuk keta & Kepadatan penduduk & Masuk dalam kategori padat & \\
\hline Defilun huta & Keragaman penggunaan lahan & Terlayani seluruh fasilitias dasar & Asidiqi (2017) \\
\hline & Transportasi publik & Terlayani jalur transportasi publik & \\
\hline \multirow[t]{2}{*}{ Infrastruktur } & Jaringan bersepeda & $\begin{array}{l}\text { - Jalan arteri primer, arteri sekunder, kolektor } \\
\text { primer, kolektor sekunder harus mempunyai } \\
\text { pemisah jalur } \\
\text { - Jalan lokal primer dan lokal sekunder tidak } \\
\text { harus mempunyai pemisah jalur tetapi harus } \\
\text { marka stencil sharrow } \\
\text { - Jalan lingkungan dan jalan pejalan kaki } \\
\text { dianggap aman untuk pesepeda }\end{array}$ & \multirow[t]{2}{*}{ Policy (2014) } \\
\hline & Parkir sepeda & $\begin{array}{l}\text { Tempat parkir sepeda paling tidak berada di } \\
\text { radius } 100 \text { meter dari pintu masuk stasiun } \\
\text { angkutan umum }\end{array}$ & \\
\hline
\end{tabular}

Sumber: Zayed, 2016; Asidiqi, 2017; Policy, 2014

Dalam penelitian ini terdapat dua tahap analisis yaitu analisis tingkat kesiapan dan tingkat prioritas kepentingan Kota Surakarta dalam konteks kota nyaman bersepeda. Selanjutnya pada analisis tingkat kesiapan tidak digunakan teknik sampling tertentu dikarenakan data yang dibutuhkan berupa data sekunder yang diperoleh dari instansi terkait. Sedangkan untuk analisis tingkat kepentingan digunakan salah satu teknik dari purposive sampling yaitu expert sampling opinion dimana digunakan pendapat/pemikiran dari seorang spesialis/ahli yang memiliki kemampuan intelektual di bidangnya. Untuk menentukan pihak-pihak yang terkait dalam hal ini stakeholder dari pemerintah, maka ditelusuri dengan studi literatur berdasarkan tupoksi dalam Perwali Surakarta No 27-C Tahun 2016 dan informasi terkait mengenai institusi maupun lembaga yang menangani Kota Nyaman Bersepeda. Setelah itu, dalam penentuan justifikasi pengaruh serta jumlahnya dilakukan melalui analisis stakeholder mapping dimana justifikasi penentuan didasarkan tupoksi serta tingkat kepentingan dan tingkat pengaruh stakeholder terkait dalam pengembangan Kota Surakarta sebagai kota nyaman bersepeda. Hasil dari analisis stakeholder mapping dapat dilihat dalam tabel berikut: 


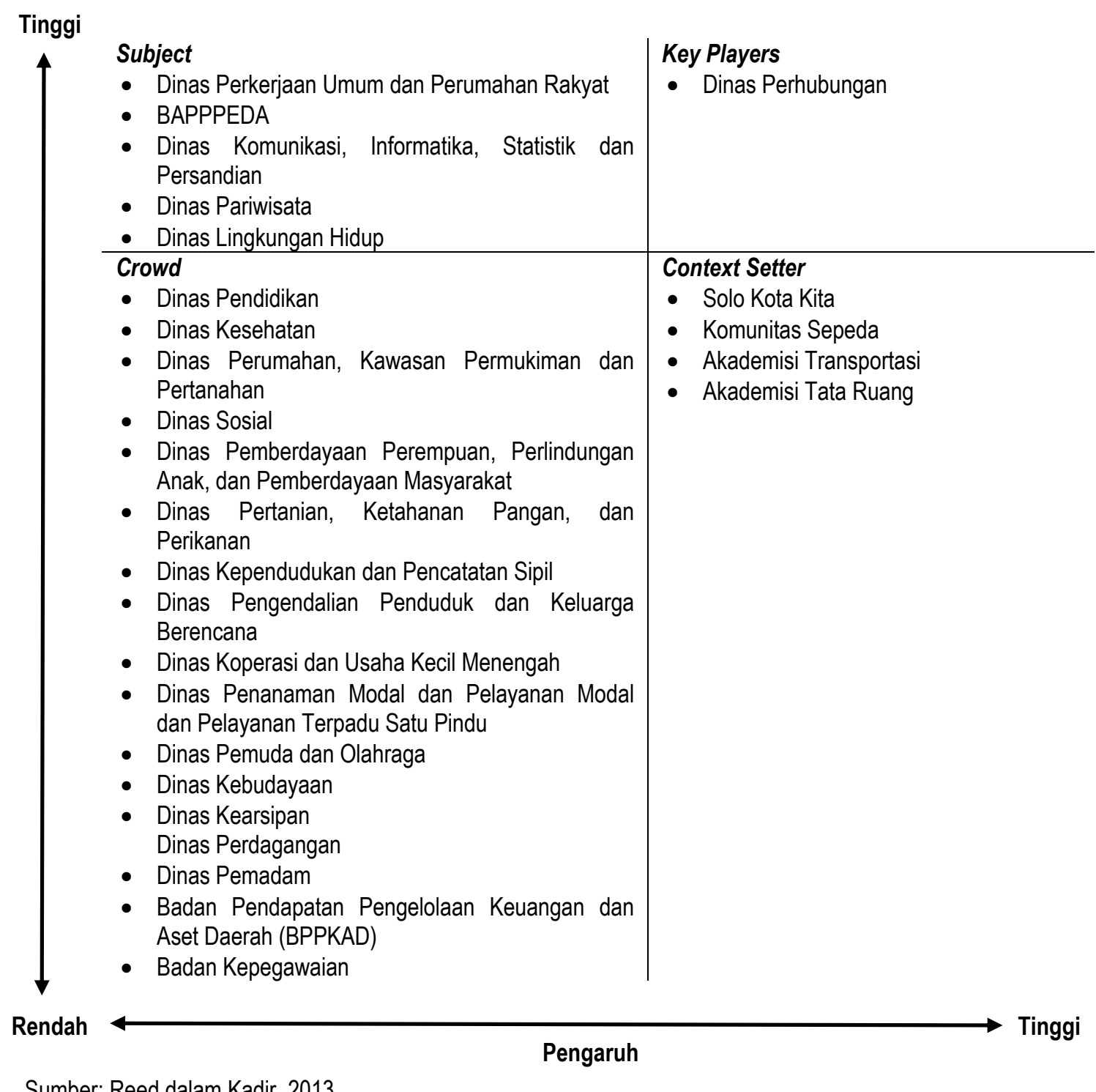

Gambar 1. Matriks Analisis Stakeholder Mapping

Dari matriks di atas diambil key player, context setter, dan subject yang kemudian ditentukan sampel setiap satu stakeholder satu perwakilan (lihat Gambar 1). Total 13 sampel yang dibutuhkan dalam penelitian ini. Teknik analisis yang digunakan adalah teknik analisis deskriptif yang diperlukan diperlukan untuk mendiskripsikan kesiapan di setiap variabel spasial yang sudah terdapat parameter untuk tolok ukur. Kemudian teknik analisis kedua yaitu Analytical Hierarchy Process (AHP) yang digunakan untuk mengetahui tingkat kepentingan variabel yang digunakan dalam penelitian ini.

\section{HASIL DAN PEMBAHASAN}

Berikut merupakan pembahasan mengenai penggalian data serta analisis yang dilakukan di setiap variabel penelitian yang kemudian dikaitkan dengan parameter yang telah didapatkan dari berbagai teori.

\subsection{KEBIJAKAN DAN KELEMBAGAAN}

Dalam kota nyaman bersepeda dibutuhkan peran serta dari pemerintah kota melalui peraturan atau kebijakan yang diatur dalam kotanya. Karena dalam konteks ini dalam lingkup sebuah kota, maka kebijakan dalam kota lebih penting untuk penerapannya. Pada penelitian ini didasarkan pada sebuah deklarasi kota nyaman bersepeda yang merupakan salah satu kebijakan yang dapat menjadi payung bagi kebijakan mengenai bersepeda yang lain. Salah satu usaha lain dari pemerintah Kota Surakarta yang berkerjasama dengan Satuan Lalu Lintas yaitu dengan membuat MoU mengenai larangan bagi siswa yang berangkat ke sekolah tidak boleh membawa sepeda motor dan menyarankan untuk 
menggunakan sepeda. Hal ini selain untuk mengurangi jumlah kendaraan bermotor di jalan juga dapat mengurangi angka kecelakaan di bawah umur. Hal ini juga mendukung rencana pemerintah untuk menggalakkan siswa ke sekolah menggunakan sepeda (bike to school). Selain bike to school terdapat rencana bike to work yaitu menggunakan alat transportasi bersepeda untuk bekerja. Pada awalnya akan diterapkan pada seluruh Pegawai Negeri Sipil yang berkerja di seluruh lembaga instansi di Kota Surakarta setiap satu kali dalam seminggu yaitu hari Jumat. Namun, berdasarkan informasi Dinas Perhubungan pada Tahun 2019, diketahui bahwa hal ini tidak terlaksana karena beberapa faktor antara lain jarak tempuh dari tempat tinggal dan tempat bekerja yang jauh dan medan jalur sepeda yang belum siap.

Pada tahun 2017 juga sudah diuji coba kotak ruang henti khusus sepeda dan becak dengan ukuran 3x4 m di sisi utara Persimpangan Gendengan. Ruang henti ini digunakan untuk memprioritaskan pesepeda dan pengayuh becak serta pemakai kendaraan non mesin lainnya agar bisa jalan terlebih dulu, setelah traffic light menyala hijau. Pada saat ini masih dalam tahap evaluasi dan jika kebijakan tersebut terbukti positif rencananya akan diperbanyak di setiap persimpangan yang sudah ada APILL, dan volume kendaraan non mesin memang cukup tinggi. Rencana kedepannya hal yang dilakukan pemerintah terakit dengan kebijakan mengenai kota nyaman bersepeda adalah dengan membuat jalur khusus untuk anak sekolah yang pada tahun 2020 akan mulai dilaksanakan di Kecamatan Banjarsari mengingat jumlah sekolah terbanyak tedapat di kecamatan tersebut.

Dalam hal kelembagaan yang berkaitan dengan bersepeda di Kota Surakarta sendiri instansi formal yang berwenang untuk mengatur adalah Dinas Perhubungan bidang Lalu Lintas, sedangkan untuk lembaga informal terdapat Non Goverment Organization (NGO) yaitu Solo Kota Kita yang berperan aktif dengan melakukan berbagai penyuluhan dan pengembangan untuk mewujudkan kota nyaman bersepeda. Selian itu terdapat berbagai komunitas sepeda yang saat ini terdapat beberapa macam antara lain Komunitas BMX dan Downhill, Komunitas Sepeda Federal Solo Raya, Komunitas Sepeda Trial Bike, Komunitas Onthel Lawas Solo, Komunitas Sepeda Lipat. Komunitas ini juga turut aktif dalam berbagai sosialisasi yang dilakukan. Melihat kondisi sekarang di Kota Surakarta sendiri masih minim kebijakan atau peraturan mengenai bersepeda untuk yang dilegalkan dan ditetapkan walaupun dari kelembagaan cukup memadai.

\subsection{LUAS WILAYAH}

Luas wilayah Kota Surakarta mencapai $44,04 \mathrm{~km}^{2}$ yang terbagi dalam 5 kecamatan, yaitu Kecamatan Laweyan, Serengan, Pasar Kliwon, Jebres dan Banjarsari. Sebagian besar lahan dipakai sebagai tempat pemukiman sebesar $66 \%$. Sedangkan untuk kegiatan ekonomi juga memakan tempat yang cukup besar juga yaitu berkisar antara $17 \%$ dari luas lahan yang ada. Dengan mengetahui luas wilayah suatu kota maka dapat diketahui pula rata-rata lama perjalanan yang ditempuh pengendara sepeda, karena semakin kecil wilayah semakin pendek jalan yang tempuh berarti lama perjalanan semakin sedikit pula.

\subsection{JUMLAH PENDUDUK}

Kota Surakarta dengan luas wilayah 44,04 km² didiami penduduk sebanyak 516.102 jiwa, terdiri dari 266.724 laki-laki dan 278.929 jiwa perempuan. Penduduk ini tersebar di 5 (lima) kecamatan yaitu Kecamatan Laweyan, Kecamatan Serengan, Kecamatan Pasar Kliwon, Kecamatan Jebres, dan Kecamatan Banjasari dengan jumlah penduduk terbesar terdapat di Kecamatan Banjarsari yaitu 173.145 jiwa (31,73 persen), sedangkan Kecamatan Serengan memiliki jumlah penduduk terkecil yaitu 52.998 Jiwa (9,71 persen). Jumlah penduduk akan mempengaruhi langsung jumlah kendaraan untuk melakukan pergerakan. Hal ini dapat mempengaruhi kenyamanan bersepeda dimana semakin banyak jumlah pergerakan maka kenyamanan pergerakan juga akan semakin berkurang.

\subsection{PERBANDINGAN PEMILIHAN MODA}

Pemilihan moda transportasi ini juga dapat mempengaruhi kenyamanan bersepeda dimana semakin banyak kendaraan bermotor dibandingkan kendaraan tidak bermotor dapat membuat risiko yang lebih tinggi pada pengguna sepeda. Transportasi umum di Kota Surakarta berupa berupa Batik Solo Trans (BST) dan angkutan umum berupa feeder. Selain menggunakan angkutan umum, masyarakat di Kota Surakarta menggunakan kendaraan pribadi baik itu bermotor maupun tidak bermotor. Hal ini dapat dilihat dalam Tabel 3. 
Tabel 3. Jumlah Kendaraan Bermotor dan Tidak Bermotor di Kota Surakarta

\begin{tabular}{|c|c|c|c|c|}
\hline \multirow{2}{*}{ No } & \multirow{2}{*}{ Jenis Kendaraan } & \multicolumn{3}{|c|}{ Jumlah (Unit) } \\
\hline & & Tahun 2015 & Tahun 2016 & Tahun 2017 \\
\hline \multicolumn{5}{|c|}{ Kendaraan Bermotor (Umum dan Pribadi) } \\
\hline 1 & Sepeda Motor & 391.963 & 560.596 & 581.979 \\
\hline \multirow[t]{4}{*}{2} & Mobil Penumpang & & & \\
\hline & a. Umum & 1.407 & 1.709 & 1.786 \\
\hline & b. Tidak Umum & 36.230 & 77.376 & 82.092 \\
\hline & c. Dinas & - & 2.926 & 2.950 \\
\hline \multirow[t]{4}{*}{3} & Mobil Barang & & & \\
\hline & a. Umum & 645 & 35.513 & 35.580 \\
\hline & b. Tidak Umum & 20.577 & 29.412 & 30.241 \\
\hline & c. Dinas & - & 247 & 270 \\
\hline \multirow[t]{4}{*}{4} & Bus Besar & & & \\
\hline & a. Umum & 1.036 & 1.405 & 1.463 \\
\hline & b. Tidak Umum & 517 & 809 & 852 \\
\hline & c. Dinas & - & 92 & 98 \\
\hline \multicolumn{5}{|c|}{ Kendaraan Tidak Bermotor (Umum dan Pribadi) } \\
\hline 1 & Becak & 2.135 & 1.281 & 1.267 \\
\hline 2 & Bendi & 90 & 90 & 90 \\
\hline & Lain-lain & 52.416 & 52.392 & 52.275 \\
\hline \multicolumn{5}{|c|}{ Jumlah } \\
\hline
\end{tabular}

Dalam tabel tersebut terlihat bahwa pengguna jalan terbanyak didominasi oleh sepeda motor dengan peningkatan yang terjadi setiap tahunnya. Dengan demikian dapat dihitung perbandingan pemilihan moda dengan data kepemilikan kendaraan. Perhitungannya dihitung sebagai berikut:

$$
\text { Perbandingan permilihan moda }=\frac{\text { Jumlah kendaraan bermotor }}{\text { Jumlah kendaraan tidak bermotor }}=\frac{737.311}{53.632}=13,74
$$

Hasil di atas menunjukkan bahwa sarana transportasi pergerakan masyarakat di Kota Surakarta didominasi oleh kendaraan bermotor dengan rasio perbandingan 13,74 .

\subsection{BENTUK KOTA}

Kota Surakarta memiliki luas lahan terbangun seluas $42,28 \mathrm{~km}^{2}$ dan pajang perimeter dari lahan yang terbangun sepanjang $91,73 \mathrm{~km}$. Sehingga dapat dihitung rasio kekompakan.

$$
c=2 \sqrt{\pi \cdot A} / P=2 \sqrt{3,14.42,28} / 91,73=0,16
$$

Jadi, rasio kekompakkan Kota Surakarta bernilai 0,16. Dari hasil tersebut Kota Surakarta tidak termasuk kedalam parameter bentuk kota nyaman bersepeda karena dilihat terlalu kompak/padat karena hanya dilihat dari segi lahan terbangun saja. Oleh karena itu diperlukan faktor lain yang digunakan untuk melihat kekompakkan Kota Surakarta. Dalam Asidiqi (2017), terdapat tiga komponen untuk dapat melihat urban compactness yaitu kepadatan yang tinggi, keragaman penggunaan lahan (mix use), dan transportasi publik. Agar dapat dilihat tingkat kekompakkan melalui tiga komponen tersebut maka akan dirinci pada skala kelurahan dikarenakan penggunaan jarak tempuh pada pesepeda juga terbatas.

\section{a. Kepadatan Penduduk}

Kepadatan penduduk dapat mempengaruhi tingkat kekompakkan suatu kota, dikarenakan kepadatan berpengaruh pada intensitas pemanfaatan lahan. Kepadatan yang rendah menyebabkan adanya dispersi perkotaan yang artinya tidak terhubungnya suatu kawasan dengan kawasan lainnya, sehingga hal ini dapat mempengaruhi kenyaman bersepeda karena jarak dari suatu wilayah ke wilayah lain cukup jauh. Kepadatan penduduk Kota Surakarta dapat dilihat dengan membandingkan jumlah keseluruhan penduduk dengan luas wilayah yang ada di setiap kelurahan Kota Surakarta. Penggolongannya tingkat kepadatan diklasifikasikan dengan Undang-Undang No 56 Tahun 1960. Kepadatan penduduk di setiap kelurahan dapat dilihat pada Tabel 4. Dimana seluruh kelurahan mempunyai tingkat kepadatan 
cukup padat dan hanya satu kelurahan yang padat. Hal ini memenuhi kriteria kekompakkan bahwa kepadatan penduduk harus padat agar mengurangi dispersi perkotaan. Berikut merupakan kategori kepadatan penduduk.

Tabel 4. Kategori Kepadatan Penduduk

\begin{tabular}{ccc}
\hline No & Kepadatan Penduduk (jiwa/km2) & Tingkat Kepadatan \\
\hline 1 & $0-50$ & Tidak Padat \\
2 & $51-250$ & Cukup Padat \\
3 & $251-400$ & Padat \\
4 & $>400$ & Sangat Padat \\
\hline \multicolumn{3}{c}{ Sumber: Undang-Undang Nomor 56 Tahun 1950 }
\end{tabular}

\section{b. Keragaman Penggunaan Lahan (Mix Use)}

Untuk melihat keragaman penggunaan lahan dapat dilihat dari variasi jenis penggunaan lahan di suatu kawasan. Semakin banyak jenis kegiatan dalam wilayah tersebut maka dapat dikatakan kawasan tersebut dapat memenuhi untuk kebutuhan kegiatannya. Dimana dalam hal ini yang dapat mendukung pesepeda untuk memperpendek jarak untuk menempuh fasilitas di suatu kawasan.

Fasilitas yang digunakan untuk menganalisis keragaman penggunaan lahan disesuaikan dengan standar sarana dasar permukiman yaitu SNI 03-1733-2004 tentang Perencanaan Lingkungan Perumahan di Perkotaan. Sarana dasar tersebut mencakup fasilitas pendidikan, kesehatan, peribadatan, perdagangan dan jasa, kebudayaan dan rekreasi, ruang terbuka hijau dan lapangan olahraga, serta fasilitas pemerintahan dan pelayanan. Semakin lengkap fasilitas yang disediakan oleh tiap wilayah (dalam hal ini dirinci setiap keluarahan) maka semakin tinggi tingkat kekompakkan keluarahan tersebut. Semakin nyaman pula pesepeda untuk menjangkau berbagai fasilitas. Kelurahan yang lengkap terlayani seluruh fasilitas dapat dilihat pada Gambar 2. menggunakan yang akan di-overlay dengan kriteria lain.

\section{c. Transportasi Publik}

Kota Surakarta mempunyai transpotasi publik berupa Batik Solo Trans (BST) adalah angkutan massal berupa bus rapid transit yang melayani Kota Surakarta dan sekitarnya meliputi daerah pinggirannya yaitu Kabupaten Karanganyar, Boyolali dan Sukoharjo. Selain bus, Batik Solo Trans juga memiliki transportasi feeder yang menggunakan angkot dengan koridor yang bervariasi. Namun, untuk transportasi umum yang mampu mengakomodasi pesepeda dimana terdapat ruang untuk menaruh sepeda untuk saat ini adalah bus BST. Sedangkan feeder hanya untuk mengangkut pergerakan orang saja. Adapun kelurahan yang terlewati rute bus BST dapat dilihat pada overlay Gambar 2.

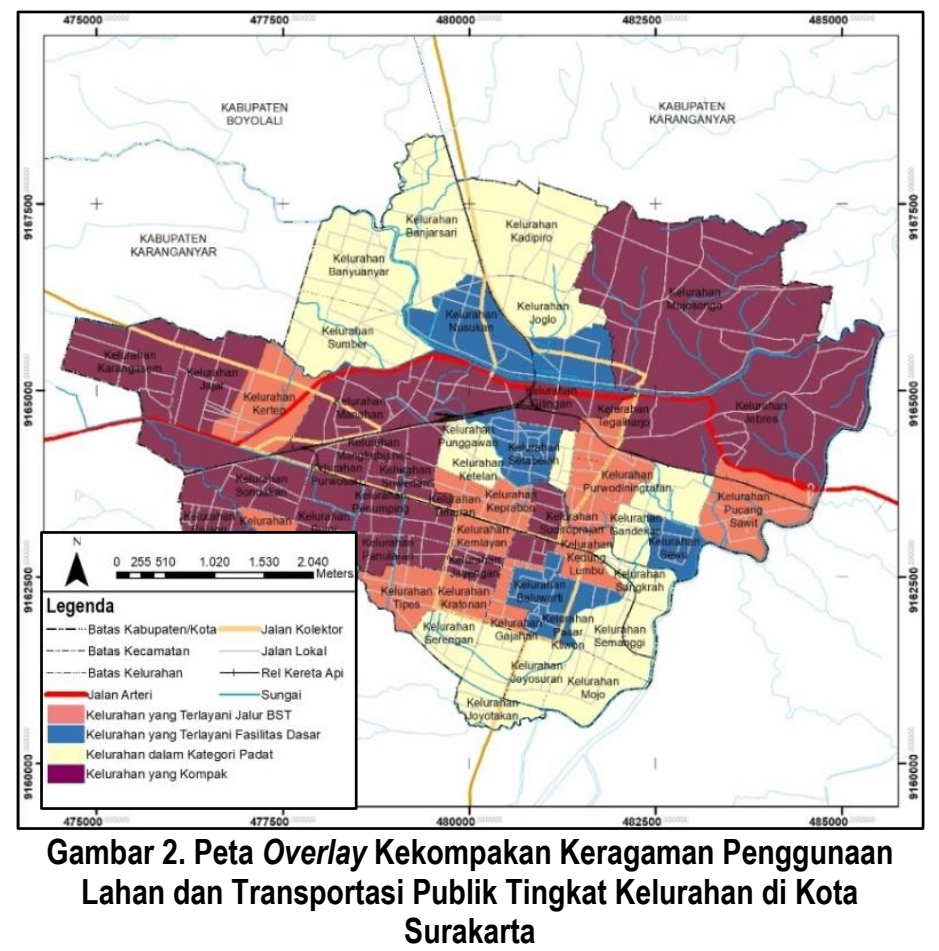


Tabel 5 merupakan hasil analisis mengenai kekompakkan Kota Surakarta yang dilihat dalam 3 kategori.

Tabel 5. Pemenuhan Kriteria Bentuk Kota yang Kompak

\begin{tabular}{|c|c|c|c|c|}
\hline Kecamatan & Kelurahan & $\begin{array}{l}\text { Kepadatan } \\
\text { Penduduk }\end{array}$ & $\begin{array}{c}\text { Keragaman } \\
\text { Penggunaan Lahan }\end{array}$ & Transportasi Publik \\
\hline \multirow{11}{*}{ Laweyan } & Pajang & $\sqrt{ }$ & $\sqrt{ }$ & $\sqrt{ }$ \\
\hline & Laweyan & $\sqrt{ }$ & - & $\sqrt{ }$ \\
\hline & Bumi & $\sqrt{ }$ & $\sqrt{ }$ & $\sqrt{ }$ \\
\hline & Panularan & $\sqrt{ }$ & $\sqrt{ }$ & $\sqrt{ }$ \\
\hline & Sriwedari & $\sqrt{ }$ & $\sqrt{ }$ & $\sqrt{ }$ \\
\hline & Penumping & $\sqrt{ }$ & $\sqrt{ }$ & $\sqrt{ }$ \\
\hline & Purwosari & $\sqrt{ }$ & $\sqrt{ }$ & $\sqrt{ }$ \\
\hline & Sondakan & $\sqrt{ }$ & $\sqrt{ }$ & $\sqrt{ }$ \\
\hline & Kerten & $\sqrt{ }$ & - & $\sqrt{ }$ \\
\hline & Jajar & $\sqrt{ }$ & $\sqrt{ }$ & $\sqrt{ }$ \\
\hline & Karangasem & $\sqrt{ }$ & $\sqrt{ }$ & $\sqrt{ }$ \\
\hline \multirow{13}{*}{ Banjarsari } & Mangkubumen & $\sqrt{ }$ & $\sqrt{ }$ & - \\
\hline & Timuran & $\sqrt{ }$ & - & $\sqrt{ }$ \\
\hline & Keprabon & $\sqrt{ }$ & - & $\sqrt{ }$ \\
\hline & Ketelan & $\sqrt{ }$ & - & - \\
\hline & Punggawan & $\sqrt{ }$ & - & - \\
\hline & Kestalan & $\sqrt{ }$ & $\sqrt{ }$ & - \\
\hline & Setabelan & $\sqrt{ }$ & $\sqrt{ }$ & - \\
\hline & Gilingan & $\sqrt{ }$ & $\sqrt{ }$ & $\sqrt{ }$ \\
\hline & Manahan & $\sqrt{ }$ & $\sqrt{ }$ & $\sqrt{ }$ \\
\hline & Sumber & $\sqrt{ }$ & - & - \\
\hline & Nusukan & $\sqrt{ }$ & $\sqrt{ }$ & - \\
\hline & Kadipiro & $\sqrt{ }$ & - & - \\
\hline & Banyuanyar & $\sqrt{ }$ & - & - \\
\hline \multirow{11}{*}{ Jebres } & Kepatihan Kulon & $\sqrt{ }$ & - & - \\
\hline & Kepatihan Wetan & $\sqrt{ }$ & - & $\sqrt{ }$ \\
\hline & Sudiroprajan & $\sqrt{ }$ & - & $\sqrt{ }$ \\
\hline & Gandekan & $\sqrt{ }$ & - & - \\
\hline & Sewu & $\sqrt{ }$ & $\sqrt{ }$ & - \\
\hline & Pucangsawit & $\sqrt{ }$ & - & $\sqrt{ }$ \\
\hline & Jagalan & $\sqrt{ }$ & - & - \\
\hline & Purwodiningratan & $\sqrt{ }$ & - & $\sqrt{ }$ \\
\hline & Tegalharjo & $\sqrt{ }$ & - & $\sqrt{ }$ \\
\hline & Jebres & $\sqrt{ }$ & $\sqrt{ }$ & $\sqrt{ }$ \\
\hline & Mojosongo & $\sqrt{ }$ & $\sqrt{ }$ & $\sqrt{ }$ \\
\hline \multirow{7}{*}{ Serengan } & Joyotakan & $\sqrt{ }$ & - & - \\
\hline & Danukusuman & $\sqrt{ }$ & - & - \\
\hline & Serengan & $\sqrt{ }$ & - & - \\
\hline & Tipes & $\sqrt{ }$ & - & - \\
\hline & Kratonan & $\sqrt{ }$ & - & $\sqrt{ }$ \\
\hline & Jayengan & $\sqrt{ }$ & $\sqrt{ }$ & $\sqrt{ }$ \\
\hline & Kemlayan & $\sqrt{ }$ & - & $\sqrt{ }$ \\
\hline \multirow{9}{*}{ Pasar Kliwon } & Joyosuran & $\sqrt{ }$ & - & - \\
\hline & Semanggi & $\sqrt{ }$ & - & - \\
\hline & Pasar Kliwon & $\sqrt{ }$ & $\sqrt{ }$ & - \\
\hline & Baluwarti & $\sqrt{ }$ & $\sqrt{ }$ & - \\
\hline & Gajahan & $\sqrt{ }$ & - & $\sqrt{ }$ \\
\hline & Kauman & $\sqrt{ }$ & $\sqrt{ }$ & $\sqrt{ }$ \\
\hline & Kampung Baru & $\sqrt{ }$ & $\sqrt{ }$ & $\sqrt{ }$ \\
\hline & Kedung Lumbu & $\sqrt{ }$ & - & $\sqrt{ }$ \\
\hline & Sangkrah & $\sqrt{ }$ & - & - \\
\hline
\end{tabular}


Berdasarkan tabel di atas, terlihat bahwa belum semua kelurahan terpenuhi syarat untuk mewujudkan kota yang kompak, hal ini dapat mempengaruhi kenyamanan bersepeda di kelurahan tersebut, sehingga masih diperlukan upaya untuk menerapkan tingkat kesiapan yang dibutuhkan (lihat Tabel 5).

\subsection{Infrastuktur}

a. Jaringan Jalan/Jalur Sepeda

Jaringan jalan/jalur sepeda adalah jalur yang khusus diperuntukkan untuk lalu lintas pengguna kendaraan tidak bermotor. Di Kota Surakarta sendiri jalur sepeda menggunakan jalur lambat yaitu jalan yang diperuntukkan bagi kendaraan yang dikemudikan dengan kecepatan rendah. Jalur ini dapat dilalui sepeda, becak, maupun bendi, namun dalam konteksnya tidak menggangu kenyaman bersepeda dikarenakan merupakan kendaraan yang berkecepatan rendah sehingga tidak membahayakan satu sama lain. Jadi, dalam pembahasan jalur sepeda peneliti menggunakan jalur lambat dengan pertimbangan di Kota Surakarta terdapat kendaraan lain yang berkecepatan rendah yang samasama menggunakan jalur yang sama. Jalur lambat ini ada di sepanjang jalan protokol Kota Surakarta (lihat Gambar 3). Untuk melihat apakah sudah terpenuhinya infrastuktur berupa jalur untuk pesepeda maka digolongkan terlebih dahulu fungsi jalan yang ada di Surakarta. Fungsi jalan yang ada di Kota Surakarta dibedakan menjadi arteri, kolektor, lokal, dan lingkungan. Sedangkan pada Kota Surakarta kategorisasi fungsi jalan arteri dan kolektor yang harus mempunyai jalur khusus sepeda dapat dilihat pada tabel berikut:

Tabel 6. Ketersediaan Jalur Lambat menurut Fungsi Jalan Arteri dan Kolektor

\begin{tabular}{clll}
\hline No & \multicolumn{1}{c}{ Nama Jalan } & \multicolumn{1}{c}{ Fungsi Jalan } & Ketersediaan Jalur Lambat Eksisting \\
\hline 1. & Jl. Brigjen Slamet Riyadi & Jalan Arteri Primer & Ada \\
2. & Jl. Ir Sutami & Jalan Arteri Primer & Ada \\
3. & Jl. Tentara Pelajar & Jalan Arteri Primer & Ada \\
4. & Jl. Letjen A. Yani & Jalan Arteri Primer & Ada sebagian \\
5. & Jl. Ki Mangun Sarkoro & Jalan Kolektor Primer & Tidak ada \\
6. & Jl. Jendral Urip Sumoharjo & Jalan Kolektor Primer & Ada \\
7. & Jl. Adi Sucipto & Jalan Kolektor Primer & Ada \\
8. & Jl. Sam Ratulangi & Jalan Kolektor Primer & Tidak ada \\
9. & Jl. Kol. Sugiono & Jalan Kolektor Primer & Tidak ada \\
10. & Jl. Honggowongso & Jalan Kolektor Primer & Tidak ada \\
11. & Jl. Jendral Sudirman & Jalan Kolektor Primer & Tidak ada \\
12. & Jl. Kapten Mulyadi & Jalan Kolektor Primer & Ada sebagian \\
13. & Jl. Brigjen Katamso & Jalan Kolektor Primer & Ada \\
14. & Jl. Mr. Sartono & Jalan Kolektor Primer & Tidak ada \\
15. & Jl. Kol. Sugiono & Jalan Kolektor Primer & Tidak ada \\
16. & Jl. Kapten Tendean & Jalan Kolektor Primer & Tidak ada \\
17. & Jl. Brigjen Sudiarto & Jalan Kolektor Primer & Tidak ada \\
18. & Jl. Mayor Sunaryo & Jalan Kolektor Primer & Tidak ada \\
19. & Jl. Veteran & Jalan Kolektor Primer & Tidak ada \\
\hline
\end{tabular}

Sumber: Dinas Perhubungan Kota Surakarta, 2018; Observasi Lapangan, 2018

Dari Tabel 6 terlihat tidak semuanya fungsi jalan arteri maupun kolektor memiliki jalur lambat. Dimana hal ini tidak sesuai dengan teori, bahwa kategori fungsi jalan arteri primer, arteri sekunder, kolektor primer, dan kolektor sekunder harus mempunyai lajur khusus sepeda yang terlindungi untuk kedua arahnya untuk menjamin keamanan dan kenyamanan bersepeda. Sedangkan untuk jalan kolektor di Kota Surakarta hanya terdapat satu jalan yang mempunyai jalur lambat dan terdapat petunjuk khusus untuk jalur sepeda yaitu Jalan Dr. Radjiman pada ruas jalan Sabar Motor sampai Singosaren. Kondisi jalan yang sudah mempunyai jalur lambatpun bervariasi dari yang berlubang dan belum diaspal sampai digunakan parkir kendaraan bermotor (lihat Gambar 3). 


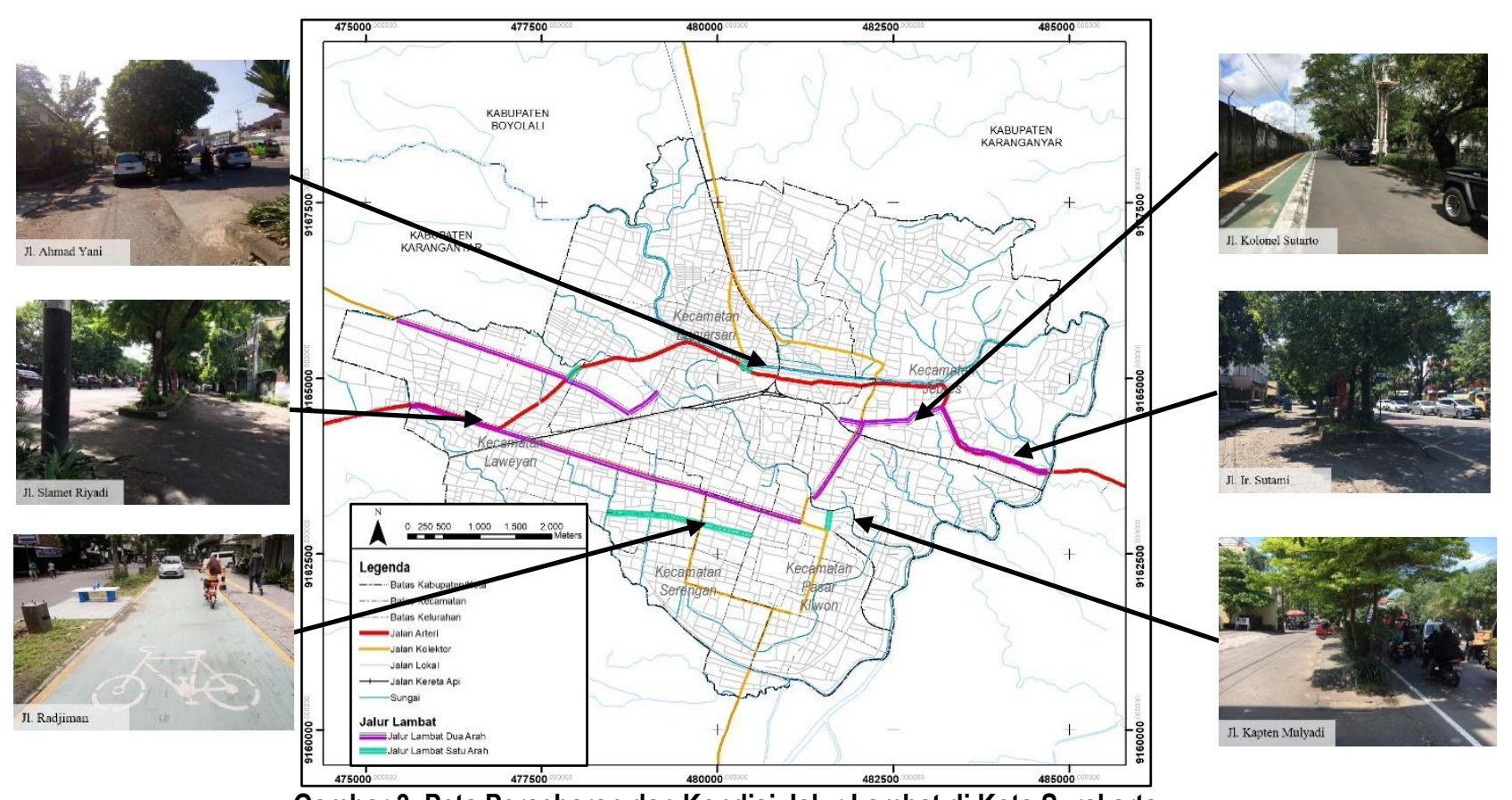

Gambar 3. Peta Persebaran dan Kondisi Jalur Lambat di Kota Surakarta

\section{b. Parkir sepeda}

Parkir sepeda adalah tempat untuk memarkirkan sepeda yang biasanya dilengkapi dengan perangkat untuk mengunci, merantai sepeda pada rak sepeda. Fasilitas untuk mengunci atau merantai sepeda pada rak sepeda diperlukan untuk menjaga keamanan sepeda.

Kondisi parkir sepeda di Kota Surakarta dikatakan masih sangat minim. Parkir khusus sepeda hanya terdapat di beberapa titik saja yaitu di citywalk Slamet Riyadi dan di depan Rumah Walikota Loji Gandrung (lihat Gambar 4). Untuk fasilitas parkir di stasiun angkutan umum (Terminal Tirtonadi dan Stasiun Balapan) masih menyatu dengan parkir kendaraan bermotor (share parking), tidak ada rak khusus untuk mengunci sepeda. Hal ini sangat riskan terjadinya pencurian sepeda. Untuk biaya retribusi parkir digratiskan khusus untuk parkir sepeda.

Untuk mobilitas ke lintas wilayah pemerintah sudah mengupayakan parkir di beberapa halte bus BST dan rencananya berdasarkan penuturan dari Dinas Perhubungan, setiap halte akan dipasangi parkir khusus sepeda. Hal ini merupakan langkah yang baik karena dapat menghubungkan sepeda dengan transportasi umum.

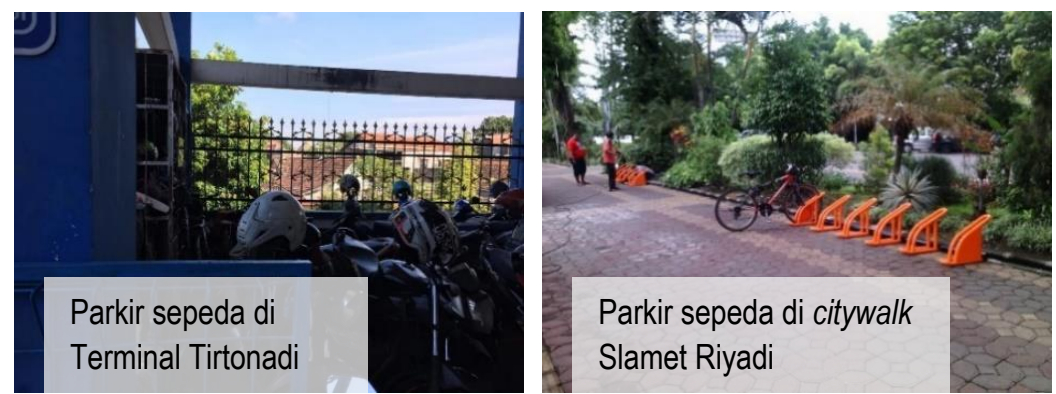

Gambar 4. Kondisi Parkir di beberapa titik di Kota Surakarta 


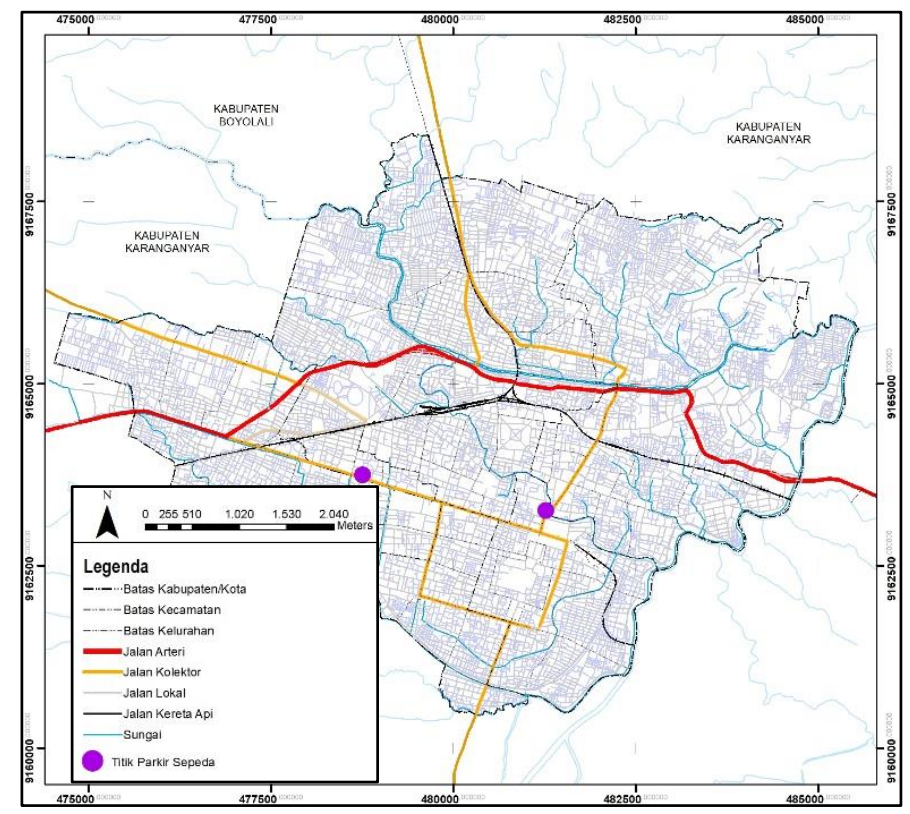

Gambar 5. Peta Titik Parkir Sepeda di Kota Surakarta

Dari gambar di atas, terlihat parkir khusus sepeda sangat sedikit dan tidak adanya parkir khusus di stasiun angkutan tidak ada sehingga masih perlu upaya untuk menambah dan mengembangan parkir sepeda di Kota Surakarta (lihat Gambar 5).

\subsection{Sosial Kebudayaan}

Untuk meningkatkan kebudayaan bersepeda sudah cukup bervariasi yang dilakukan. Mulai dari sosialisasi keselamatan berkendara/safety riding menggunakan helm dalam event Solo Ramah Bersepeda, kemudian ada simulasi bersepeda yang tertib yang menggandeng perempuan di Kota Surakarta melalui perwakilan di setiap kader kelurahan. Selain itu ada mengajak berkeliling di Kota Surakarta dengan rute yang telah ditentukan. Hal ini merupakan usaha dari pemerintah Kota Surakarta bersama LSM Solo Kota Kita dan komunitas sepeda yang ada di Surakarta dan sekitarnya. Kegiatan yang rutin dilakukan sebagai usaha meningkatkan iklim bersepeda yaitu Car Free Day (CFD). Dalam kegiatan ini dapat digunakan sebagai tempat sosialisasi ataupun menarik masyarakat untuk bersepeda dan mengurangi jumlah kendaraan bermotor di hari minggu. Berikut merupakan rangkuman hasil analisis setiap variabel (lihat Tabel 9).

Tabel 9. Rangkuman Hasil Analisis Setiap Variabel

\begin{tabular}{|c|c|c|c|c|}
\hline Variabel & Sub Variabel & Parameter & Hasil Penelitian & Keterangan \\
\hline Luas wilayah & - & $49,4 \mathrm{~km}^{2}-891,6 \mathrm{~km}^{2}$ & 44,04 & $\begin{array}{l}\text { Siap, dengan } \\
\text { pertimbangan } \\
\text { mendekati range }\end{array}$ \\
\hline $\begin{array}{l}\text { Jumlah } \\
\text { penduduk }\end{array}$ & - & 223.200 jiwa - 3.292 .400 jiwa & 516.102 & Siap \\
\hline $\begin{array}{l}\text { Perbandingan } \\
\text { pemilihan moda }\end{array}$ & - & $0,1-1,9$ & 13,74 & Tidak siap \\
\hline \multirow[t]{4}{*}{ Bentuk kota } & $\begin{array}{l}\text { Rasio kekompakkan } \\
\text { kota }\end{array}$ & $0,2-0,8$ & 0,16 & Tidak siap \\
\hline & Kepadatan penduduk & Masuk dalam kategori padat & Padat & Siap \\
\hline & $\begin{array}{l}\text { Keragaman } \\
\text { penggunaan lahan }\end{array}$ & Terlayani seluruh fasilitias dasar & $\begin{array}{l}\text { Tidak semua } \\
\text { terjangkau }\end{array}$ & Tidak siap \\
\hline & Transportasi Publik & Terlayani jalur transportasi publik & $\begin{array}{l}\text { Tidak semua } \\
\text { terjangkau jalur } \\
\text { transportasi publik }\end{array}$ & Tidak siap \\
\hline Infrastruktur & Jaringan bersepeda & $\begin{array}{l}\text { - Jalan arteri primer, arteri } \\
\text { sekunder, kolektor primer, kolektor } \\
\text { sekunder harus mempunyai } \\
\text { pemisah jalur } \\
\text { - Jalan lokal primer dan lokal }\end{array}$ & $\begin{array}{l}\text { Belum adanya } \\
\text { pemisah jalur di semua } \\
\text { jalan arteri dan kolektor }\end{array}$ & Tidak siap \\
\hline
\end{tabular}




\begin{tabular}{|c|c|c|c|c|}
\hline Variabel & Sub Variabel & Parameter & Hasil Penelitian & Keterangan \\
\hline \multicolumn{5}{|c|}{$\begin{array}{l}\text { sekunder tidak harus mempunyai } \\
\text { pemisah jalur tetapi harus marka } \\
\text { stencil sharrow } \\
\text { - Jalan lingkungan dan jalan pejalan } \\
\text { kaki dianggap aman untuk } \\
\text { pesepeda }\end{array}$} \\
\hline & Parkir sepeda & $\begin{array}{l}\text { Tempat parkir sepeda paling tidak } \\
\text { berada di radius } 100 \text { meter dari pintu } \\
\text { masuk stasiun angkutan umum }\end{array}$ & $\begin{array}{l}\text { Tidak adanya tempat } \\
\text { parkir khusus di } \\
\text { stasiun angkutan } \\
\text { umum }\end{array}$ & Tidak siap \\
\hline
\end{tabular}

\subsection{Analisis Tingkat Kepentingan Variabel Kota Nyaman Bersepeda}

Pada analisis tingkat kepentingan variabel kota nyaman bersepeda teknik yang digunakan adalah teknik analisis Analytical Hierarchy Processs (AHP). Data yang digunakan untuk menganalisis tingkat kepentingan tersebut yaitu berupa masukkan penilaian perbandingan kriteria yang diberikan oleh stakeholder terkait atau yang memahami kota nyaman bersepeda. Untuk media analisis prioritas digunakan Aplikasi Software Expert Choice 11. Gambar 6 merupakan hasil dari prioritas kepentingan yang telah dilakukan Software Expert Choice 11.

Combined instance -- Synthesis with respect to: Goal: TINGKAT KEPENTINGAN VARIABEL KOTA NYAMAN BERSEPEDA. DI KOTA SURAKARTA

Overall Inconsistency $=, 01$

Jaringan/ Lajur Sepeda
Kebijakan dan Lembaga
Perbandingan Pemilihan Moda
Sosial Kebudayaan
Parkir Sepeda
Bentuk Kota
Jumlah Penduduk
Luas Wilayah

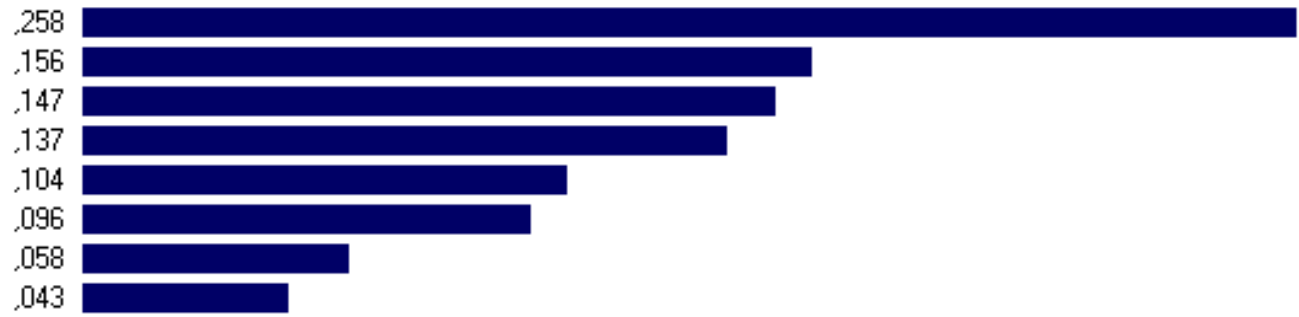

Gambar 6. Diagram Prioritas Variabel Kota Nyaman Bersepeda di Kota Surakarta

Dari hasil AHP di atas, didapatkan bahwa urutan teratas dari prioritas kepentingan adalah subfaktor dari infrastruktur yaitu jaringan/lajur sepeda yang mana nilainya sangat tinggi yatu 0,258 yang mempunyai jarak yang banyak dengan prioritas kedua (lihat Gambar 6). Jaringan/jalur sepeda dianggap menjadi faktor yang penting dikarenakan merupakan fasilitas pokok yang harus terpenuhi untuk menjadi kota nyaman bersepeda. Apabila jalur sepeda sudah baik baik kuantitas maupun kualitas maka pesepeda juga akan nyaman berada di jalur tersebut.

Variabel prioritas kedua adalah kebijakan dan lembaga. Dimana kebijakan dianggap faktor yang penting dikarenakan apabila sudah ada kebijakan yang ketat untuk pesepeda agar dihargai masyarakat maka pesepeda juga akan merasa aman. Kebijakan dapat mengatur seperti yang sudah dilakukan yaitu menetapkan Kota Surakarta sebagai kota nyaman bersepeda.

Variabel prioritas yang terpenting peringkat ketiga adalah perbandingan pemilihan moda, dimana variabel ini juga penting bagi kenyamanan bersepeda dikarenakan dengan jumlah kendaraan bermotor yang ada di jalan lebih banyak dan sangat banyak dapat membahayakan pengguna sepeda. Jalur yang seharusnya digunakan untuk sepeda tetapi digunakan untuk kendaraan bermotor apalagi fenomena yang terjadi sekarang banyak jalur sepeda yang digunakan untuk parkir kendaraan bermotor.

Dari ketiga prioritas variabel teratas apabila disimpulkan seharusnya infrastuktur seperti jalur sepeda diperbanyak dan diperbaiki agar kualitas dan kuantitas dapat memadai sehingga dapat menjangkau dari seluruh wilayah di Kota Surakarta namun harus diperhatikan juga jumlah kendaraan bermotor yang melintas di jalan dikarenakan apabila jumlahnya sangat banyak maka akan mengurangi kenyamanan dan keamanan sehingga perlu adanya kebijakan yang jelas akan kendaraan bermotor tidak mengalami peningkatan. 


\section{KESIMPULAN}

Berdasarkan hasil analisis yang telah dilakukan dalam penelitian, terdapat 7 variabel yang digunakan untuk mengetahui kesiapan Kota Surakarta sebagai kota nyaman bersepeda yaitu kebijakan dan kelembagaan, luas wilayah, jumlah penduduk kota, bentuk kota, infrastuktur yang dibagi menjadi jalur dan parkir sepeda, perbandingan pemilihan moda transportasi, dan sosial kebudayaan bersepeda dengan hanya 2 variabel yang termasuk dalam kategori siap. Hal ini menunjukkan bahwa masih banyak hal yang harus dilakukan dan memerlukan kerjasama antar berbagai pihak untuk mempersiapkan Kota Surakarta sebagai kota nyaman bersepeda. Langkah-langkah lain seharusnya bisa didorong dengan kebijakan-kebijakan mengenai bersepeda agar pesepeda nyaman di jalan seperti pembatasan penggunaan kendaraan bermotor bisa menggunakan dengan peraturan dari kebijakan misalnya dengan membuat aturan batas tertentu kepemilikan kendaraan bermotor atau dengan membuat jalur yang memutar untuk kendaraan bermotor sehingga orang akan lebih memilih untuk menggunakan sepeda atau transportasi umum atau dengan menaikkan tarif pajak kendaraan bermotor sehingga masyarakat "dipaksa" untuk mengganti kendaraan pribadinya dan dapat mengendalikan jumlah kendaraan bermotor.

Sedangkan urutan kepentingan prioritas yaitu dengan urutan adalah jaringan/jalur sepeda, kebijakan dan kelembagaan, perbandingan pemilihan moda, sosial kebudayaan bersepeda, parkir sepeda, bentuk kota, jumlah penduduk, dan urutan terakhir adalah luas wilayah. Urutan ini didasarkan pada stakeholder terkait yang dianggap ahli dalam hal ini, sehingga diharapkan untuk kedepannya dilakukan perbaikkan yang disesuaikan dengan tingkat prioritas kepentingan dimana pada saat ini jaringan/jalur sepeda dianggap paling penting di Kota Surakarta untuk mewujudkan kota nyaman bersepeda.

\section{DAFTAR PUSTAKA}

Adisasmita, S. (2012). Perencaaan Infrastruktur Transportasi Wilayah. Yogyakarta: Graha IImu.

Anderson, J. (1979). Public Policy Making, (Second ed.). New York: Holt Renehart and Winston.

Asidiqi, H. (2017). Pengaruh Urban Compactness Terhadap Tingkat Ketersediaan Ruang Terbuka Hijau di Kawasan Solo Baru. Arsitektura,15(1), 27-34. https://doi.org/10.20961/arst.v15i1.11384

Badan Pusat Statistik. (2017). Kota Surakarta dalam Angka 2017. Diakses dari https://surakartakota.bps.go.id/publication/2017/08/16/c70e0b4680351cc99240cbfa/kota-surakarta-dalam-angka-2017.html

Badan Pusat Statistik. (2018). Data Jumlah Kendaraan Bermotor dan Tidak Bermotor di Kota Surakarta

Copenhagenize. (2011). The Copenhagenize Index Bicycle Friendly City. Diakses dari: https://copenhagenizeindex.eu/criteria.html

Dinas Perhubungan Kota Surakarta. (2018). Data Jumlah Kendaraan Bermotor dan Tidak Bermotor di Kota Surakarta

Dinas Perhubungan Kota Surakarta. (2018). Ketersediaan Jalur Lambat menurut Fungsi Jalan Arteri dan Kolektor

Elkin, T. d. (1991). Reviving the city: towards sustainable urban developmen. London: Friends of the Earth.

Haughton, G. (1997). Developing Sustainable Urban Development Models. Cities, 14(4), 189-195. https://doi.org/10.1016/S02642751(97)00002-4

Jenks, M. (2000). Compact Cities Sustainable Urban Form for Developing Countries. USA and Canada: SPON Press.

Joo, S., Oh, C., Jeong, E., \& Lee, G. (2015). Categorizing bicycling Environments Using GPS-based Public Bicycle Speed Data. Transportation Research Part C Emerging Technologies, 56. https://doi.org/10.1016/j.trc.2015.04.012

Kadir, Abd W., dkk. (2013). Analisis Stakeholder Pengelolaan Taman Nasional Bantimulung Bulusaraung Provinsi Sulawesi Selatan. Jurnal Manusia dan Lingkungan, 20(1), 11-21 https://doi.org/10.22146/jml.18470

Kristinsdottir, S. (2012). A Bicycle Friendly City, a Possibility or a Dream? Sweden: Lund University.

Neuman, M. (2005). The Compact City Fallacy. Journal of Planning Education and Research , 25(1), 11-26. https://doi.org/10.1177/0739456X04270466

Peraturan Menteri Perhubungan Republik Indonesia Nomor PM 111 Tahun 2015 tentang Tata Cara Penetapan Batas Kecepatan. Diakses Februari, 2020 dari website http://ppid.dephub.go.id/files/datahubdat/PM_111_Tahun_2015.pdf

Peraturan Walikota Surakarta No 27-C Tahun 2016 tentang Kedudukan, Susunan. Organisasi, Tugas, Fungsi dan Tata Kerja. Diakses Februari, 2020 dari website https://organisasi.surakarta.go.id/web/files/perwali.pdf

Policy, I. f. (2014). TOD Standart. New York: Despacio.

Richardson, H. C.-H. (2000). In M. J. (Eds), Compact Cities : Sustainable Urban Forms for Developing Countries. London: Spon Press.

SNI 03-1733-2004 tentang Perencanaan Lingkungan Perumahan di Perkotaan. Diakses Februqari, 2020 dari website http://johannes.lecture.ub.ac.id/files/2012/10/Tata-Cara-Perencanaan-Lingkungan-Perumahan-di-Perkotaan-_-SNI-03-17332004.pdf

Tamin, O. Z. (2007). Menuju Terciptanya Sistem Transportasi Berkelanjutan di Kota-Kota Besar di Indonesia. Jurnal Transportasi 7(2), 87-104 87. Diakses dari http://journal.unpar.ac.id/index.php/journaltransportasi/article/view/1820 
Undang-Undang Nomor 56 Tahun 1960 tentang Penetapan Luas Lahan. Diakses Februari, 2020 dari website https://www.atrbpn.go.id/Publikasi/Peraturan-Perundangan/Undang-Undang/undang-undang-nomor-56-tahun-1960-919

UP3AD, K. S. (2014). Data Obyek Kendaraan Bermotor Menurut Jenisnya. Diakses Februari, 2020 dari UP3AD KOTA SURAKARTA, http://dppad.jatengprov.go.id/up3ad-kota-surakarta/

Wahab, S. (2005). Analisis Kebijakasanaan dari Formulasi ke. Implementasi Kebijaksanaan Negara. Jakarta: Bumi Aksara.

Williams, S. (2015). New Platium New Gold Bicycle Friendly Communities. Diakses Februari, 2020 dari The League of American Bicyclists: http://www.bikeleague.org/content/new-platinum-new-gold-bicycle-friendly-communities.

Yunus, S. (2000). Struktur Tata Ruang Kota. Yogyakarta: Penerbit Pustaka Pelajar.

Zayed, M. A. (2016). Towards an Index of City Readiness for Cycling. Transportation Science and Technology, 5(3), 210-225. https://doi.org/10.1016/j.jitst.2017.01.002 